Syntax Literate : Jurnal Ilmiah Indonesia p-ISSN: 2541-0849

e-ISSN : 2548-1398

Vol. 5, No. 8 Agustus 2020

\title{
STUDI EKSPERIMENTAL DAN ANALISIS ELEMEN RANGKA ATAP BAJA RINGAN KOMPOSIT APLUS CASTING PLASTER PADA BATANG TEKAN
}

\section{Cahyadi dan Resmi Bestari Muin}

Magister Teknik Sipil, Universitas Mercu Buana Jakarta, Indonesia

Email: pakce70@gmail.com dan resmi.bestari@mercubuana.ac.id

\section{Abstract}

Bending is a phenomenon that occurs when the rod gains a compressive force. Bending needs to be avoided to prevent failure of the building structure. The coldformed steel roof frame is one of the building structures that has a high risk of buckling, which is caused by a very thin material. One alternative to increase the bending of mild steel frames is the incorporation of new materials or what is called composite materials. Aplus casting plaster is an alternative additional material that can increase the rod's strength against bending. The ingredients in this material are calcium sulfate hemihydrate and crystalline silica. This material can be obtained in the market as a material for making ceiling trim. In this study, we want to determine the maximum load and the pattern of failure of composite and noncomposite rod elements on mild steel frames. The number of samples of each of the 18 composite and non-composite rod elements with rod element lengths is $400 \mathrm{~mm}$, $600 \mathrm{~mm}, 800 \mathrm{~mm}, 1000 \mathrm{~mm}, 1200 \mathrm{~mm}$, and $1400 \mathrm{~mm}$ respectively. The analytical method uses SNI 7971-2013 for non-composite materials and SNI 1729-2015 for composite materials, while the experimental method is carried out by using a compressive test using a UTM (Universal Testing Material) tool with gradual loading until the rod elements collapse. The results showed that composite rod elements had higher strength than non-composite rod elements between $48.35 \%$ to $86.32 \%$ with a failure pattern that occurred bending for all non-composite rod elements and local bending of some composite rod elements except for the length of the rod elements. $1200 \mathrm{~mm}$ and $1400 \mathrm{~mm}$ occur bending.

Keywords: Experimental \& Analytical; Composite Mild Steel SNI 7971-2013; SNI 1729-2015

\footnotetext{
Abstrak

Tekuk merupakan fenomena yang terjadi jika batang memperoleh gaya tekan. Tekuk perlu dihindari agar tidak terjadi kegagalan struktur bangunan. Rangka atap baja ringan merupakan salah satu struktur bangunan yang beresiko tinggi terjadinya tekuk, yang disebabkan karena material yang sangat tipis. Salah satu alternatif untuk meningkatkan tekuk pada rangka baja ringan adalah penggabungan material baru atau yang disebut material komposit. Aplus casting plaster salah satu alternatif material tambahan yang bisa meningkatkan batang kuat terhadap tekuk. Kandungan bahan yang ada pada material tersebut adalah calcium sulfate hemihidrate dan cristaline silica. Material ini bisa diperoleh dipasaran sebagai bahan pembuatan lis plafon. Pada penelitian ini ingin mengetahui beban maksimum dan pola keruntuhan
} 
elemen batang komposit dan non komposit pada rangka baja ringan. Jumlah sample masing-masing 18 elemen batang komposit dan non komposit dengan panjang elemen batang $\left(L_{k}\right)$ masing-masing $400 \mathrm{~mm}, 600 \mathrm{~mm}, 800 \mathrm{~mm}, 1000 \mathrm{~mm}, 1200 \mathrm{~mm}$ dan 1400mm. Metoda analisis menggunakan SNI 7971-2013 untuk material non komposit dan SNI 1729-2015 untuk material komposit, sedangkan metoda eksperimental dilakukan dengan uji tekan menggunakan alat UTM (Universal Testing Material) dengan pembebanan bertahap sampai elemen batang mengalami keruntuhan. Hasil penelitian menunjukan bahwa elemen batang komposit memiliki kekuatan yang lebih tinggi dari elemen batang non komposit antara $48.35 \%$ sampai dengan $86.32 \%$ dengan pola keruntuhan yang terjadi tekuk lentur untuk semua elemen batang non komposit dan tekuk lokal pada sebagian elemen batang komposit kecuali pada panjang elemen batang $\left(L_{k}\right) 1200 \mathrm{~mm}$ dan $1400 \mathrm{~mm}$ terjadi tekuk lentur.

Kata kunci: Eksperimental \& Analisis; Baja Ringan Komposit, SNI 7971-2013; SNI 1729-2015

\section{Pendahuluan}

Material baja ringan memiliki kelebihan jika dibandingkan dengan material kayu. Kelebihan yang dimiliki baja ringan diantaranya anti rayap, tahan api, pengerjaan cepat, material mudah dibentuk sesuai keinginan, memiliki bobot yang ringan, tahan cuaca, ramah lingkungan dan masih banyak kelebihan yang lainnya. Kelebihan tersebut menjadi daya tarik masyarakat untuk menggunakannya sebagai bahan bangunan rangka penutup atap yang menjadi tren saat ini. Struktur atap baja ringan merupakan struktur alternatif pengganti baja konvensional karena lebih ekonomis dan mudah diperoleh (Apriani, 2019).

Perlu menjadi perhatian baja ringan memiliki kelemahan antara lain terjadi tekuk jika beban tekan bekerja melebihi batas kekuatannya. Tekuk menjadi sebuah fenomena bagi material konstruksi khususnya pada struktur yang langsing dan penampang yang tipis. Umumnya tekuk merupakan fenomena struktur yang harus dihindari. Tekuk terjadi ketika keseimbangan struktur berada dalam ketidak-stabilan yang bisa dibarengi dengan leleh atau tidaknya material baja. Dua jenis tekuk yang sering terjadi pada baja ringan adalah tekuk lokal dan tekuk global yang antara lain dipengaruhi oleh faktor penampang atau geometri. Tekuk global yang diikuti dengan tekuk distorsional terjadi mulai dari angka kelangsungan batang $(\chi)$ sebesar 100 (Deskarta, 2018). Beban kritis buckling (tekuk) dapat diprediksi dengan menghitung nilai-nilai eigen (eigenvalues) struktur berdasarkan data propertis dan kondisi tumpuan yang ditentukan (Sumirin, 2014). Tekuk lokal merupakan kegagalan yang sering terjadi untuk elemen tekan baja ringan walaupun diberi pengaku (Aidil Fitrah, Ridho dan Herman, 2019).

Penambahan kapasitas tekan batang dipengaruhi Panjang tekuk kritis yang berkurang akibat penambahan pengaku, sedangkan cara menempatkan pengaku tidak memberikan pengaruh selama panjang tekuk kritis sama (Sandjaya \& Suryoatmono, 2018). Baja ringan memiliki beberapa fenomena keruntuhan, diantaranya terjadinya kerutan atau tekuk yang diamati pada batang tekan dan berlangsung secara tiba-tiba dan 
sangat berbahaya (Stevens, Denny dan Tedianto, 2018), terjadinya distorsi dari penampang yang ditandai oleh gerakan di garis lipatan (Stevens, Denny dan Tedianto, 2018). Sedangkan Pola Keruntuhan yang terjadi pada rangka tipe Pratt dan Howe dengan bentang teoritis $12 \mathrm{~m}$ dan $24 \mathrm{~m}$ adalah tekuk lentur (Sucipta, Saggaff, \& Muliawan, 2013). Secara umum disimpulkan bahwa baja ringan dapat digunakan sebagai elemen struktur tetapi harus diwaspadai adanya kecenderungan desain yang ramping dan rentan terhadap kegagalan stabilitas atau tekuk terhadap keseluruhan kolom, baik berupa tekuk torsi maupun tekuk lentur-torsi juga pola tekuk baik tekuk lokal dan tekuk distorsi (Stevens, Denny dan Tedianto, 2018). Berdasarkan beberapa masalah yang terjadi pada baja ringan harus dilakukan perkuatan dengan melakukan penggabungan dua material agar mampu menahan beban tekan sebagai penyebab terjadinya tekuk pada elemen rangka atap. Pengelolaan dari rantai pasok baja yang baik dapat membantu pemerintah untuk mengelola komoditas yang utamadan signifikan, serta mengidentifikasi kebutuhan koordinasi antar Kementrian terkait dengan rencana pengembanganindustri pendukung pada sektor konstruks (Andreas \& Abduh, 2013). Batang komposit merupakan salah satu alternatif agar batang mampu meningkatkan kekuatan batang terhadap tekuk. Komposit adalah suatu material yang terbentuk dari gabungan dari dua atau lebih material sehingga dihasilkan material yang mempunyai sifat mekanik dan karakteristik yang berbeda dari material pembentuknya. Struktur komposit merupakan penggabungan dua jenis material sebagai upaya memanfaatkan kelebihan dari masing-masing material untuk menciptakan struktur yang kuat dan efisien (Hayu,Gati A., Ahmad M.A., 2019).

Pada penelitian sebelumnya dengan material komposit yang berbeda bahwa baja ringan komposit kayu laminasi dapat meningkatkan kekuatan batang tekan (Irawati, Awaludin, \& Sebastian, 2017), dari hasil analisis kuda kuda baja ringan komposit kayu laminasi lebih kuat dibandingkan kuda kuda tanpa pengisi (Rahmawati \& Isnantyo, 2019). struktur kuda-kuda memiliki kapasitas beban sebesar $480 \mathrm{~kg}$ dan lendutan di tengah bentang sebesar 23,3 $\mathrm{mm}$ untuk profil $\mathrm{C}$ tunggal. Pengujian dengan menggunakan profil $\mathrm{C}$ ganda di dapat hasil yang berbeda. Kapasitas beban maksimumnya sebesar $735 \mathrm{~kg}$ dengan lendutan di tengah bentang sebesar 24,74 mm dimana lendutan di ukur pada puncak kuda-kuda (Yusuf \& Elvira, 2014). Setiap material memiliki keunggulan dan kemampuan dalam merespon kinerja struktur. Struktur komposit dalam penerapannya akan mengasumsikan bahwa setiap material yang tersusun akan bekerja sama untuk memikul kinerja struktur tersebut. Kenaikan beban tekan cukup signifikan yaitu sekitar 1,4 - 6,7 waktu anggota non-komposit. Peningkatan beban tekan terendah berhubungan dengan kompresi anggota dengan panjang anggota tertinggi (Awaludin, Rachmawati, Aryati, \& Danastri, 2015). Baja ringan komposit aplus casting plaster merupakan salah satu alternatif komposit lain yang mampu meningkatkan kekuatan elemen rangka atap baja ringan terhadap tekuk serta mudah memperoleh bahan dan pembuatannya. Model komposit ini merupakan hal yang baru yang belum diteliti oleh peneliti sebelumnya. 
Keterbaruan pada penelitian ini komposit baja ringan aplus casting plaster mampu mereduksi biaya pemasangan baja ringan dengan jarak antar kuda kuda 1.5 meter, jarak antar kuda kuda ini melebihi dari yang biasa digunakan dilapangan. Jarak antara kuda kuda yang biasa ditemukan dilapangan antara 1 meter sampai dengan 1.2 meter. Hasil perhitungan desain struktur kuda-kuda baja ringan diperoleh desain profil Batang bawah menggunakan profil C81.72 (tebal 0,7 mm), batang diagonal dan batang vertical menggunakan profil C81.100 (tebal $1 \mathrm{~mm}$ ) dan batang bawah menggunakan profil C100.100 (tebal $1 \mathrm{~mm}$ ). Sambungan baja menggunakan sekrup SDS (self drilling screw) 12-14x20 dengan df = 5,3 mm (Syamsudin, Susanti, \& Istiono, 2018). Pada penelitian ini bertujuan untuk mengetahui beban maksimum $\left(P_{\text {mak }}\right)$ yang mampu diterima oleh elemen rangka atap baja ringan komposit dan non komposit serta mengetahui pola keruntuhan yang terjadi.

\section{Metode Penelitian}

Pada penelitian studi analisis akan dilakukan desain elemen batang non komposit dengan menggunakan SNI 7971-2013 dan komposit menggunakan SNI 1729-2015, pada penelitian ini akan dianalisis secara detail menggunakan standar diatas, dari 18 sampel non komposit dan 18 sampel komposit dengan panjang elemen batang $\left(L_{k}\right)$ masing-masing $400 \mathrm{~mm}, 600 \mathrm{~mm}, 800 \mathrm{~mm}, 1000 \mathrm{~mm}, 1200 \mathrm{~mm}$ dan $1400 \mathrm{~mm}$ akan diperoleh nilai beban maksimum $\left(P_{\text {mak }}\right)$ berdasarkan analisis. Sedangkan studi eksperimental dilakukan dengan melakukan pengujian tekan elemen batang dengan menggunakan UTM (Universal Testing Material). Jumlah sampel yang digunakan pada penelitian ini berjumlah sama seperti pada penelitian studi analisis. Pada eksperimen ini elemen rangka atap baja ringan akan dibebani secara bertahap sampai batang mengalami keruntuhan dan pada saat itu diperoleh beban maksimum $\left(P_{\text {mak }}\right)$ berdasarkan eksperimen. Pada studi eksperimen akan diamati terhadap terhadap perilaku tekuk yang terjadi.

\section{Hasil dan Pembahasan}

Setelah dilakukan penelitian pada elemen rangka atap baja ringan melalui analisis dan eksperimental maka diperoleh data sebagai berikut:

Tabel 1 Rekapitulasi hasil penelitian

\begin{tabular}{ccccc}
\hline \multirow{2}{*}{$\begin{array}{c}\text { Panjang } \\
\text { Batang } \\
\left(L_{k}\right)\end{array}$} & \multicolumn{4}{c}{ Beban Maksimum $\left(P_{\text {mak }}\right)$} \\
\cline { 2 - 5 }$(\mathrm{mm})$ & $\begin{array}{c}\text { Non } \\
\text { Komposit } \\
(\mathrm{N})\end{array}$ & $\begin{array}{c}\text { Komposit } \\
(\mathrm{N})\end{array}$ & $\begin{array}{c}\text { Non } \\
\text { Komposit } \\
(\mathrm{N})\end{array}$ & $\begin{array}{c}\text { Komposit } \\
(\mathrm{N})\end{array}$ \\
\hline 400 & 20920 & 38930 & 33587.16 & 39235.06 \\
\hline 600 & 18820 & 34850 & 32410.71 & 36150.93 \\
\hline 800 & 19590 & 36060 & 31274.82 & 32236.11 \\
\hline 1000 & 16790 & 39150 & 30179.50 & 27819.15 \\
\hline 1200 & 14580 & 21630 & 29122.10 & 23233.96 \\
\hline 1400 & 13670 & 25470 & 28102.63 & 18779.35 \\
\hline
\end{tabular}


1. Berdasarkan analisis dan eksperimen beban maksimum $\left(P_{\text {mak }}\right)$ batang non komposit memiliki rasio antara 0.48 sd 0.62 , analisis menggunakan SNI 7971-2013 berdasarkan tegangan kritis komponen struktur, menunjukan bahwa beban maksimum $\left(P_{\text {mak }}\right)$ hasil analisis yang lebih besar dari beban maksimum $\left(P_{\text {mak }}\right)$ hasil eksperimen

Tabel 2 Rasio beban maksimum $\left(P_{m a k}\right)$ hasil analisis dan eksperimental batang non komposit

\begin{tabular}{|c|c|c|c|}
\hline \multirow{2}{*}{$\begin{array}{c}\text { Panjang Batang } \\
\left(L_{k}\right) \\
(\mathrm{mm})\end{array}$} & \multicolumn{2}{|c|}{$\begin{array}{l}\text { Beban Maksimum }\left(P_{\operatorname{mak}}\right) \\
\text { Berdasarkan }\end{array}$} & \multirow{2}{*}{$\begin{array}{c}\text { Rasio } \\
\left(\left(P_{m a k}\right) \text { Eksperimen }\right. \\
/ \\
\left.\left(P_{m a k}\right) \text { Analisis }\right)\end{array}$} \\
\hline & $\begin{array}{c}\text { Analisis } \\
(\mathrm{N})\end{array}$ & $\begin{array}{c}\text { Eksperime } \\
\mathrm{n} \\
(\mathrm{N})\end{array}$ & \\
\hline 400 & 33587.16 & 20920 & 0.62 \\
\hline 600 & 32410.71 & 18820 & 0.58 \\
\hline 800 & 31274.82 & 19590 & 0.62 \\
\hline 1000 & 30179.50 & 16790 & 0.56 \\
\hline 1200 & 29122.10 & 14580 & 0.50 \\
\hline 1400 & 28102.63 & 13670 & 0.48 \\
\hline
\end{tabular}

2. Berdasarkan analisis dan eksperimen beban maksimum $\left(P_{\text {mak }}\right)$ batang komposit memiliki rasio 0.96 sd 1.41, analisis menggunakan SNI 1729-2015 berdasarkan kondisi penampang badan dan penampang langsing, menunjukan bahwa beban maksimum $\left(P_{\text {mak }}\right.$ ) berdasarkan analisis pada $L_{\bar{k}} 400 \mathrm{~mm}, 600 \mathrm{~mm}$ dan $1200 \mathrm{~mm}$ lebih besar dari beban maksimum $\left(P_{\text {mak }}\right)$ hasil eksperimen, sementara untuk $L_{k}$ $800 \mathrm{~mm}$ dan $1000 \mathrm{~mm}$ beban maksimum $\left(P_{\text {mak }}\right)$ berdasarkan analisis lebih kecil dari beban maksimum $\left(P_{\text {mak }}\right)$ hasil eksperimen

Tabel 3 Rasio beban maksimum $\left(\boldsymbol{P}_{m a k}\right)$ hasil analisis dan eksperimental batang komposit

\begin{tabular}{cccc}
\hline $\begin{array}{c}\text { Panjang } \\
\text { Batang } \\
\left(L_{k}\right) \\
(\mathrm{mm})\end{array}$ & $\begin{array}{c}\text { Beban Maksimum }\left(P_{\text {mak }}\right) \\
\text { Berdasarkan } \\
(\mathrm{N})\end{array}$ & $\begin{array}{c}\text { Rasio } \\
(\mathrm{N})\end{array}$ & $\begin{array}{c}\text { Rasio } \\
\left(P_{\text {mak }}\right) \text { Eksperim } \\
\text { en/ }\end{array}$ \\
\hline 400 & 39235.06 & 38930 & 0.99 \\
\hline 600 & 36150.93 & 34850 & 0.96 \\
\hline 800 & 32236.11 & 36060 & 1.12 \\
\hline 1000 & 27819.15 & 39150 & 1.41 \\
\hline 1200 & 23233.96 & 21630 & 0.93 \\
\hline 1400 & 18779.35 & 25470 & 1.35 \\
\hline
\end{tabular}

3. Berdasarkan eksperimen beban maksimum $\left(P_{\text {mak }}\right.$ ) batang komposit antara $48.35 \%$ sd $86.32 \%$ lebih besar dari batang non komposit. Komposit baja ringan casting plaster mempunyai pengaruh besar dalam meningkatkan kekuatan batang dalam menerima beban. 


\begin{tabular}{|c|c|c|c|c|}
\hline \multirow{2}{*}{$\begin{array}{c}\text { Panjang } \\
\text { Batang } \\
\left(L_{k}\right) \\
(\mathrm{mm})\end{array}$} & \multicolumn{2}{|c|}{$\begin{array}{c}\text { Beban Maksimum }\left(P_{\operatorname{mak}}\right) \\
\text { Berdasarkan Eksperimen } \\
(\mathrm{N})\end{array}$} & \multirow{2}{*}{$\begin{array}{l}\text { Selisih } \\
(\mathrm{N})\end{array}$} & \multirow[t]{2}{*}{ Perbedaan (\%) } \\
\hline & $\begin{array}{c}\text { Non } \\
\text { komposit }\end{array}$ & Komposit & & \\
\hline 400 & 20920 & 38930 & 18010 & 86.09 \\
\hline 600 & 18820 & 34850 & 16030 & 85.17 \\
\hline 800 & 19590 & 36060 & 16470 & 84.01 \\
\hline 1000 & 16790 & 39150 & 22360 & 75.09 \\
\hline 1200 & 14580 & 21630 & 7050 & 48.35 \\
\hline 1400 & 13500 & 25470 & 11800 & 86.32 \\
\hline
\end{tabular}

4. Pola keruntuhan yang terjadi pada batang non komposit rata rata terjadi tekuk lentur, dimana batang mengalami kerusakan pada bagian tengah batang dengan rusaknya flens, lips dan web batang, yang selanjutnya batang terjadi tekuk sebelum batang leleh. Sementara pada batang komposit rata rata terjadi tekuk lokal, tekuk yang diawali dengan rusaknya batang pada bagian flens dan lips di bagian ujung yang lebih dahulu meleleh sebelum terjadi tekuk, kecuali pada $\left(L_{k}\right) 1200 \mathrm{~mm}$ dan $1400 \mathrm{~mm}$ terjadi tekuk lentur

Tabel 5 Pola keruntuhan hasil eksperimental batang non komposit dan komposit

\begin{tabular}{ccc}
\hline Panjang Batang & \multicolumn{2}{c}{ Pola Keruntuhannya } \\
\cline { 2 - 3 }$\left(L_{k}\right)$ & Non komposit & Komposit \\
\hline 400 & Tekuk Lentur & Tekuk Lokal \\
\hline 600 & Tekuk Lentur & Tekuk Lokal \\
\hline 800 & Tekuk Lentur & Tekuk Lokal \\
\hline 1000 & Tekuk Lentur & Tekuk Lokal \\
\hline 1200 & Tekuk Lentur & Tekuk Lentur \\
\hline 1400 & Tekuk Lentur & Tekuk Lentur \\
\hline
\end{tabular}

Berikut penjelasan pola keruntuhan pada batang yang tersaji dalam tabel diatas dengan menggunakan grafik hasil penelitian sebagai berikut :

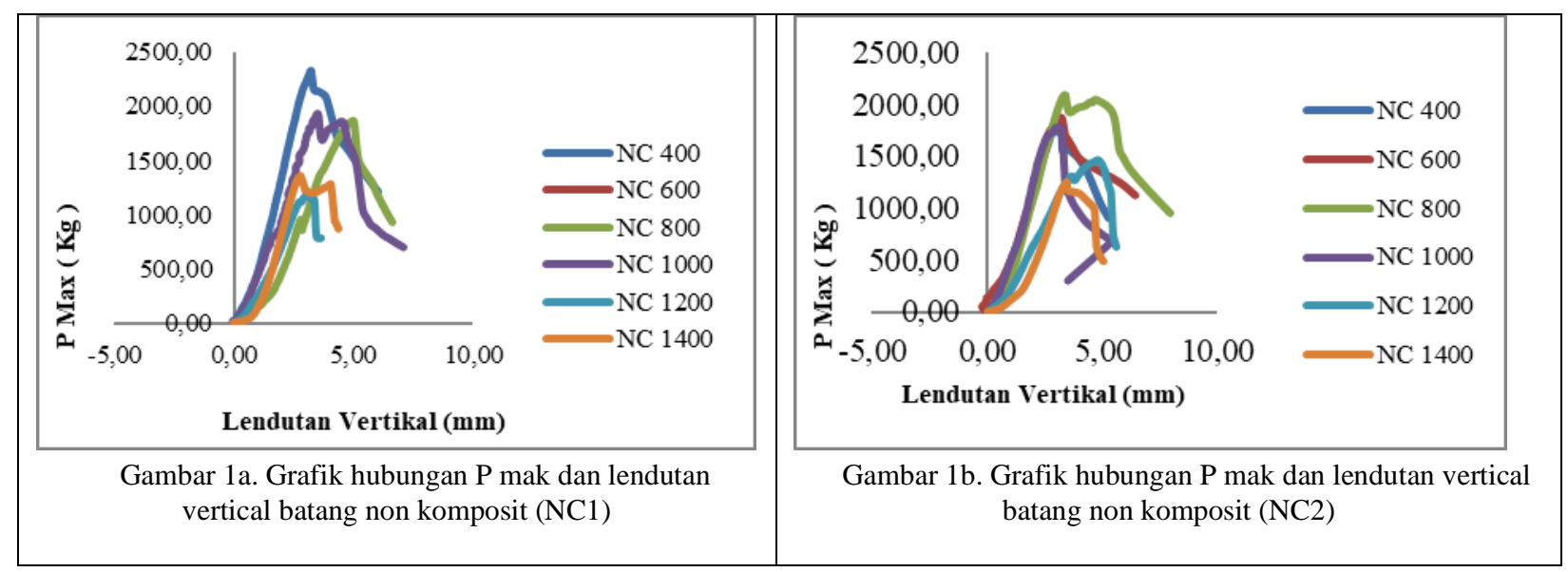




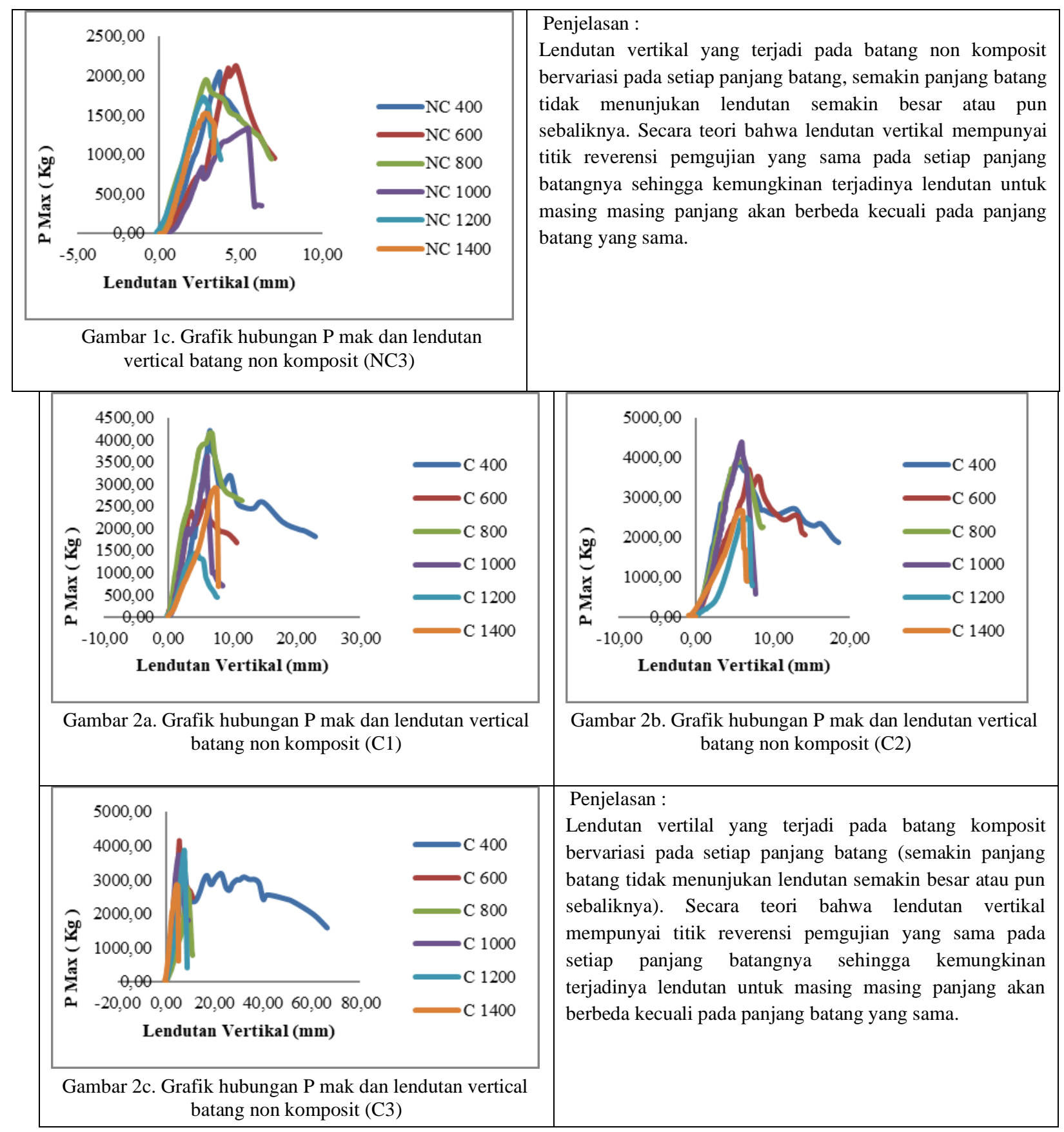




\section{Cahyadi dan Resmi Bestari Muin}

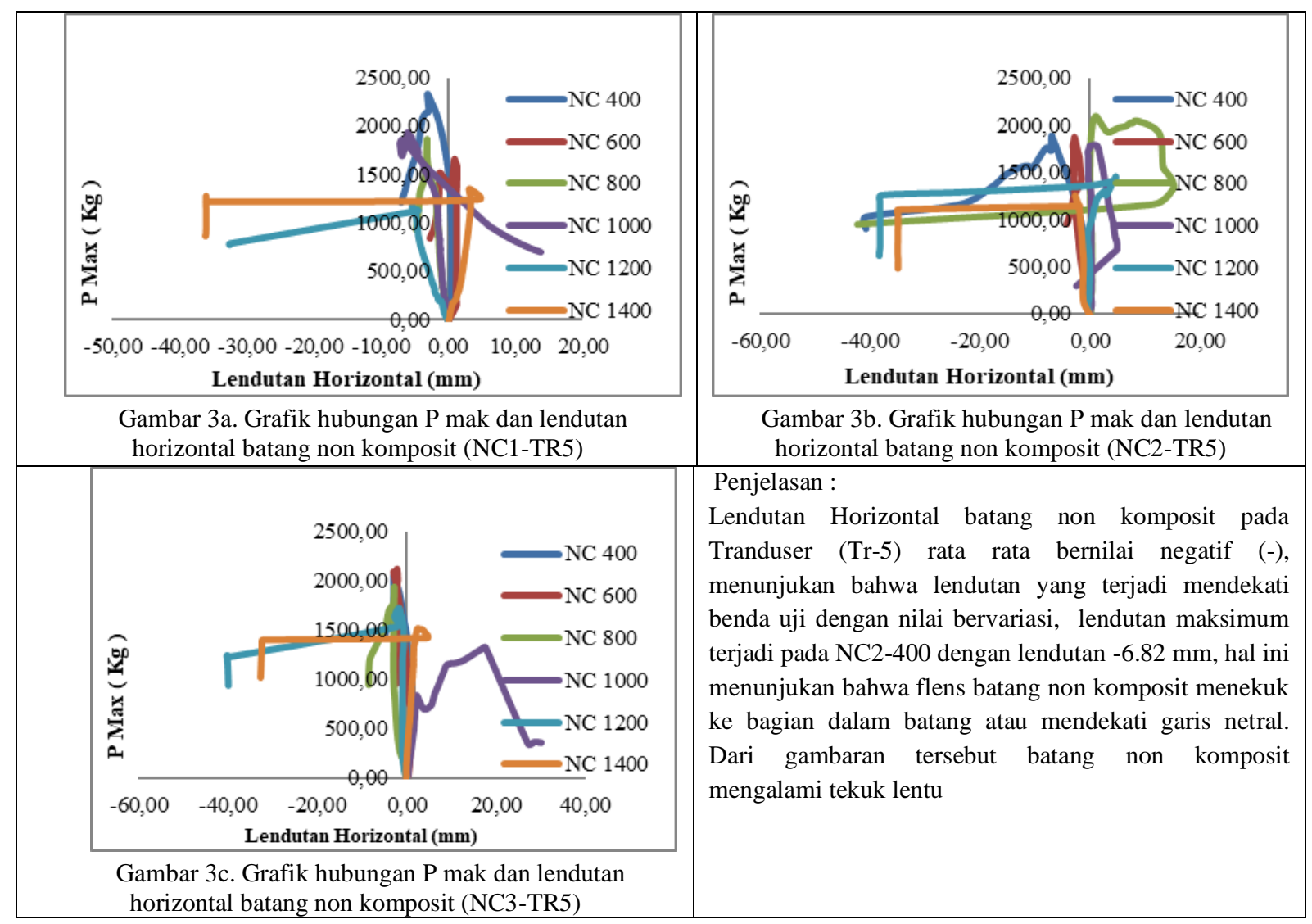

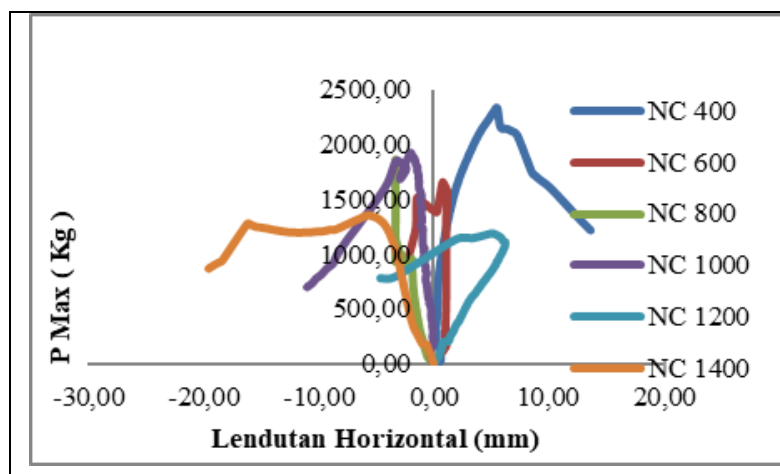

Gambar 4a. Grafik hubungan P mak dan lendutan horizontal batang non komposit (NC1-TR6)

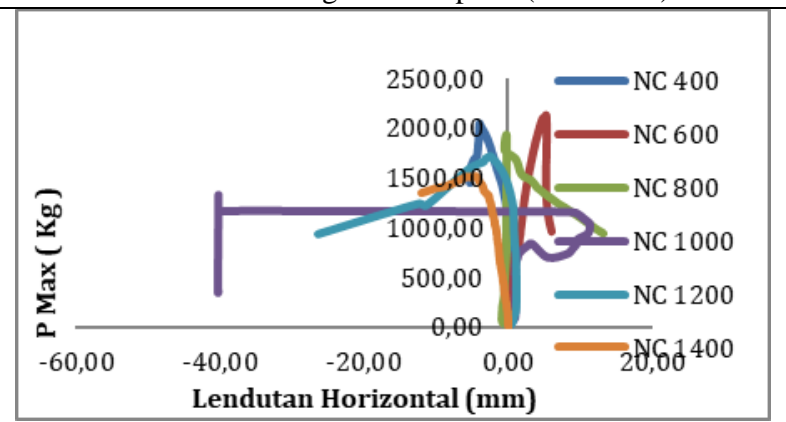

Gambar 4c. Grafik hubungan P mak dan lendutan horizontal batang non komposit (NC3-TR6)

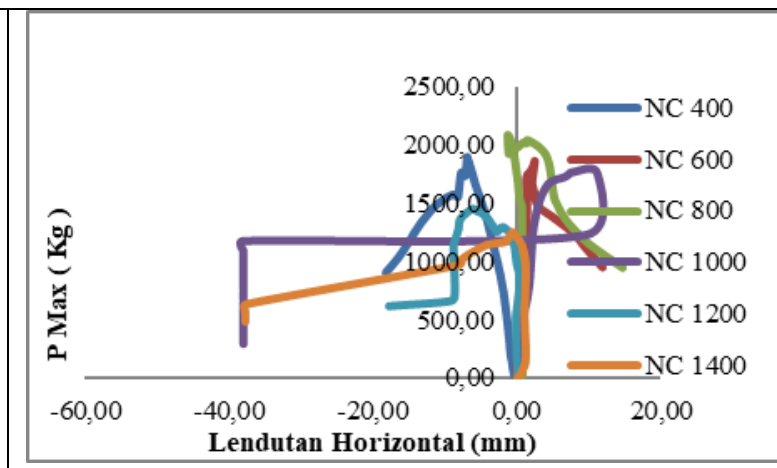

Gambar 4b. Grafik hubungan P mak dan lendutan horizontal batang non komposit (NC2-TR6)

Penjelasan :

Lendutan Horizontal batang non komposit pada Tranduser (Tr-6) rata rata bernilai negatif (-), menunjukan bahwa lendutan yang terjadi mendekati benda uji dengan nilai bervariasi, lendutan maksimum terjadi pada NC3-1000 dengan lendutan $-40.24 \mathrm{~mm}$, hal ini menunjukan bahwa flen batang non komposit menekuk ke bagian dalam batang atau mendekati garis netral. Dari gambaran tersebut batang non komposit mengalami tekuk lentur 


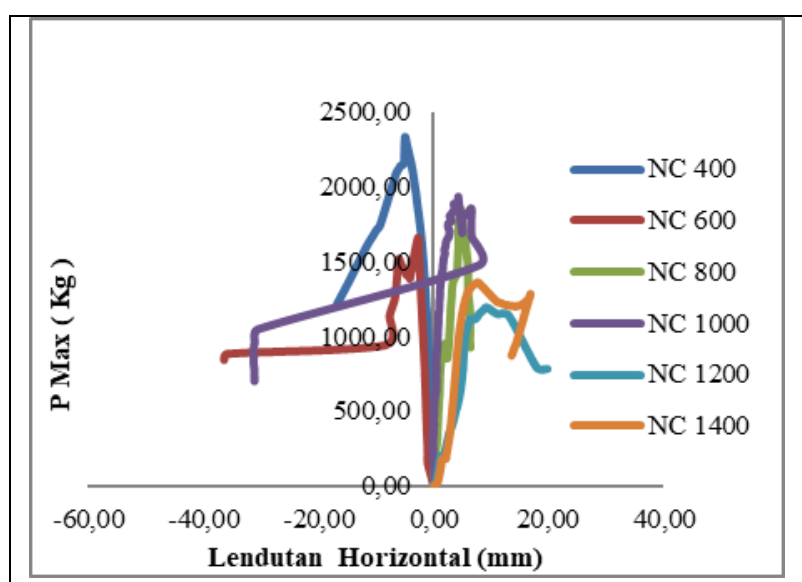

Gambar 5a. Grafik hubungan P mak dan lendutan horizontal batang non komposit (NC1-TR7)

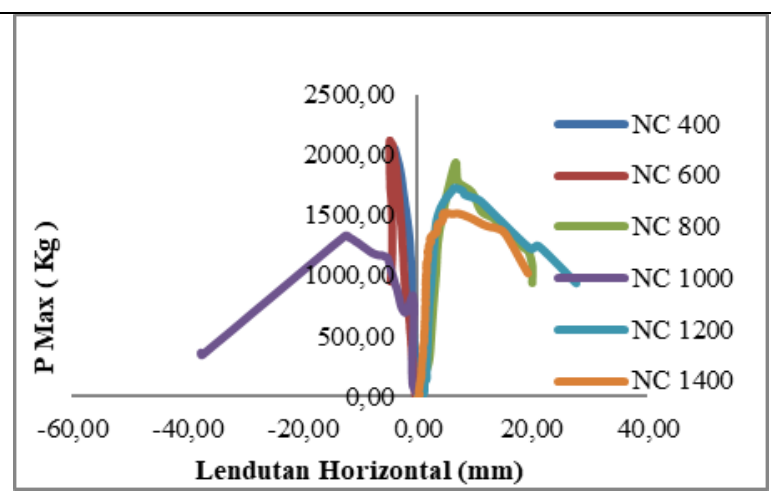

Gambar 5c. Grafik hubungan P mak dan lendutan horizontal batang non komposit (NC3-TR7)

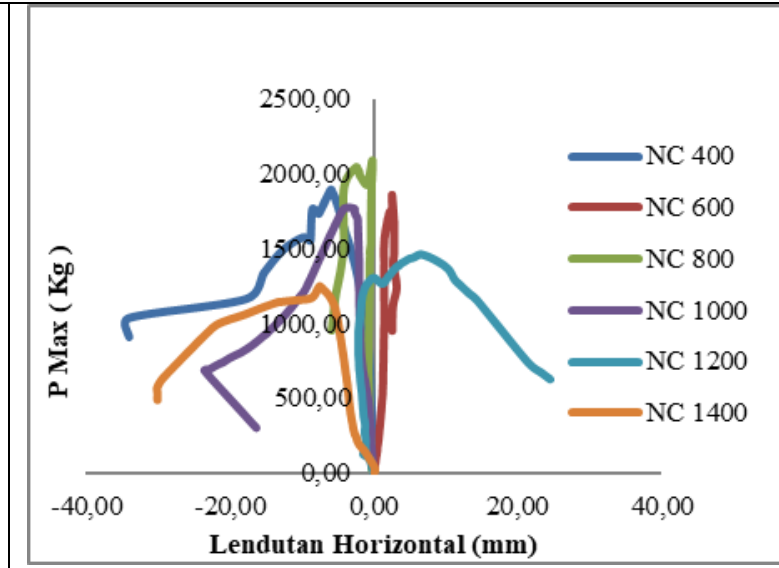

Gambar 5b. Grafik hubungan P mak dan lendutan horizontal batang non komposit (NC2-TR7)

Penjelasan :

Lendutan Horizontal batang non komposit pada Tranduser (Tr-7) hampir seimbang antara bernilai negati (-) dan bernilai positif (+), menunjukan bahwa lendutan yang terjadi ada yang menjauhi dan mendekati benda uji dengan nilai bervariasi, lendutan (+) maksimum terjadi pada NC11200 dengan lendutan $9.32 \mathrm{~mm}$, lendutan negatif (-) terjadi pada NC3-1000 dengan lendutan $-12.64 \mathrm{~mm}$, hal ini menunjukan bahwa web batang non komposit menekuk ke kebagian dalam dan keluar batang. Dari gambaran tersebut batang non komposit mengalami tekuk lentur

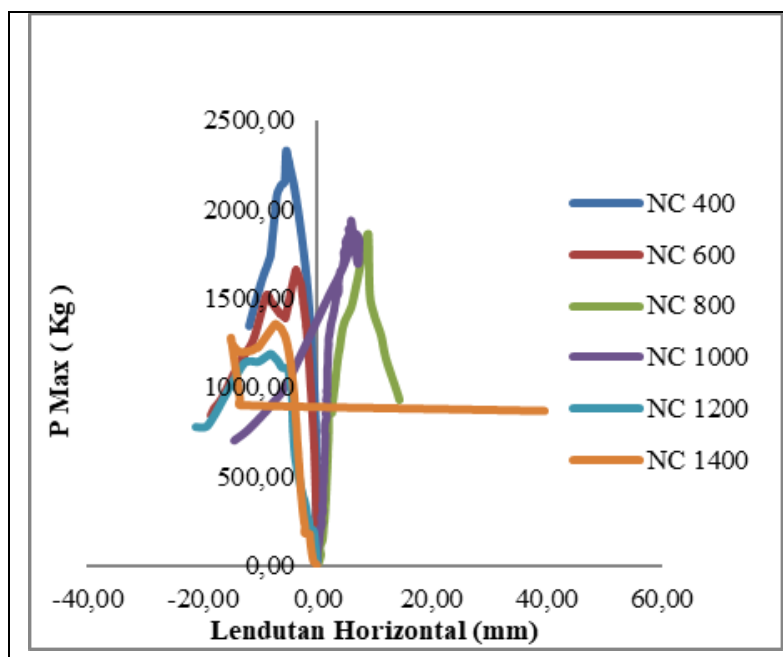

Gambar 6a. Grafik hubungan P mak dan lendutan horizontal batang non komposit (NC1-TR8)

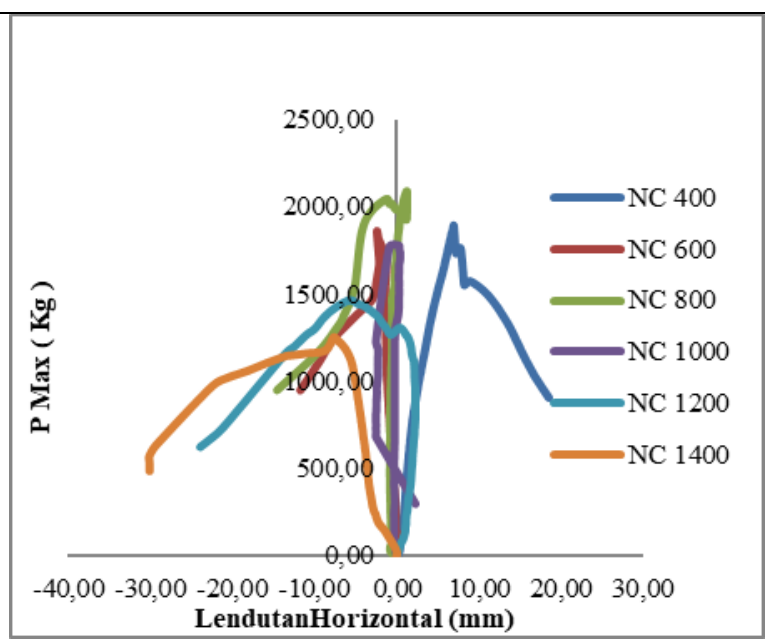

Gambar 6b. Grafik hubungan P mak dan lendutan horizontal batang non komposit (NC2-TR8) 


\section{Cahyadi dan Resmi Bestari Muin}

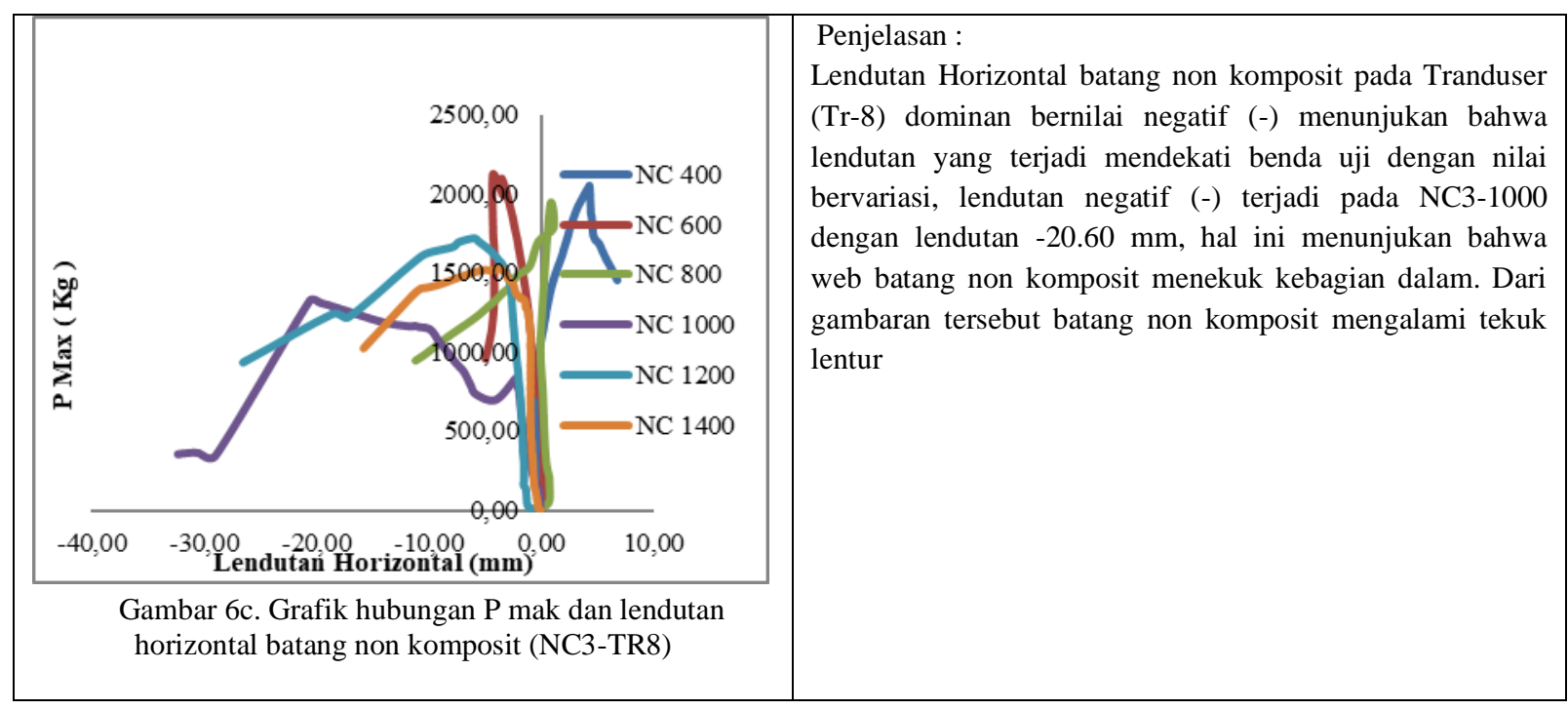

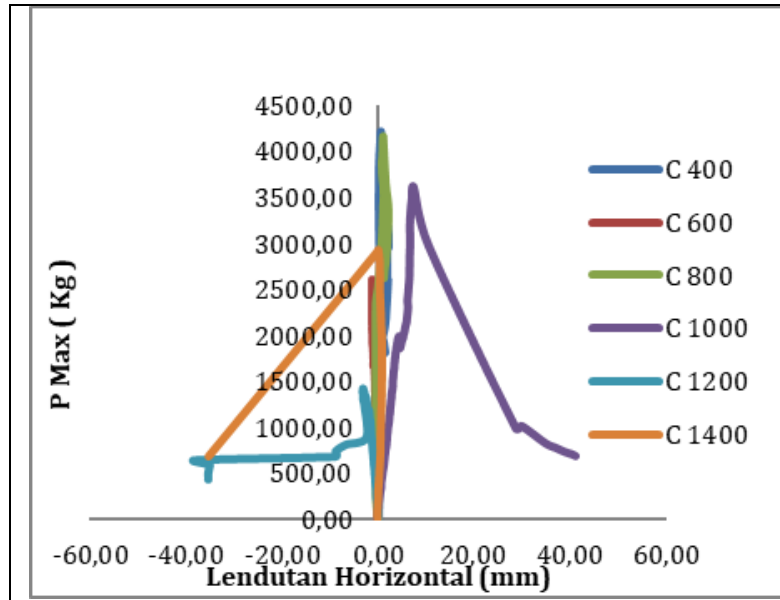

Gambar 7a. Grafik hubungan P mak dan lendutan horizontal batang komposit (C1-TR5)

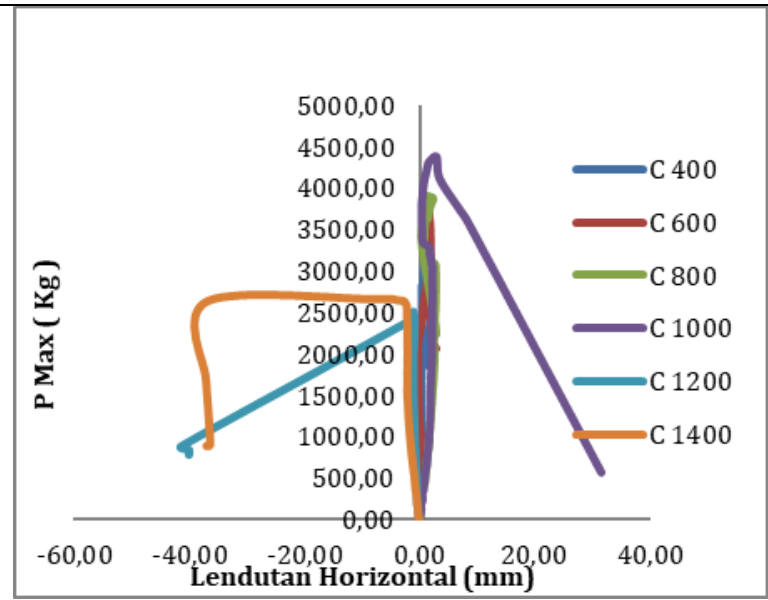

Gambar 7b. Grafik hubungan P mak dan lendutan horizontal batang komposit (C2-TR5)

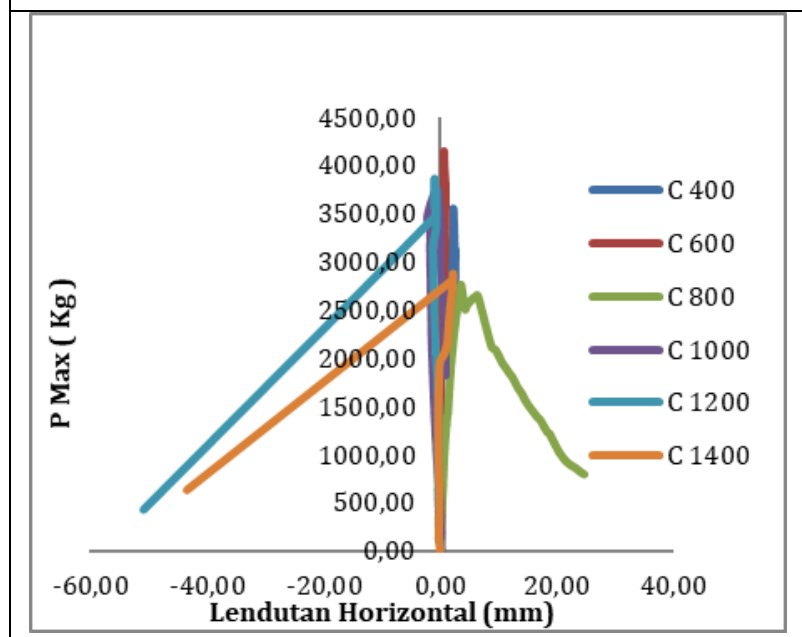

Gambar 7c. Grafik hubungan P mak dan lendutan horizontal batang komposit (C3-TR5)

\section{Penjelasan :}

Lendutan Horizontal batang komposit pada Tranduser ( $\mathrm{Tr}$ 5) bervariasi dan mendekati nol, kecuali untuk batang dengan panjang 1000,1200 dan 1400 menunjukan bahwa lendutan yang terjadi mendekati benda uji dengan nilai bervariasi, lendutan negatif (-) terjadi pada C2-1400 dengan lendutan $-7.76 \mathrm{~mm}$, hal ini menunjukan bahwa flens batang 1000, 1200 dan 1400 mengalami kerusakan dengan menekuk ke bagian dalam atau mendekati garis netral. Dari gambaran diatas pada batang komposit terjadi kerusakan pada bagian atas atau bawah batang yang menunjukkan terjadi tekuk lokal 


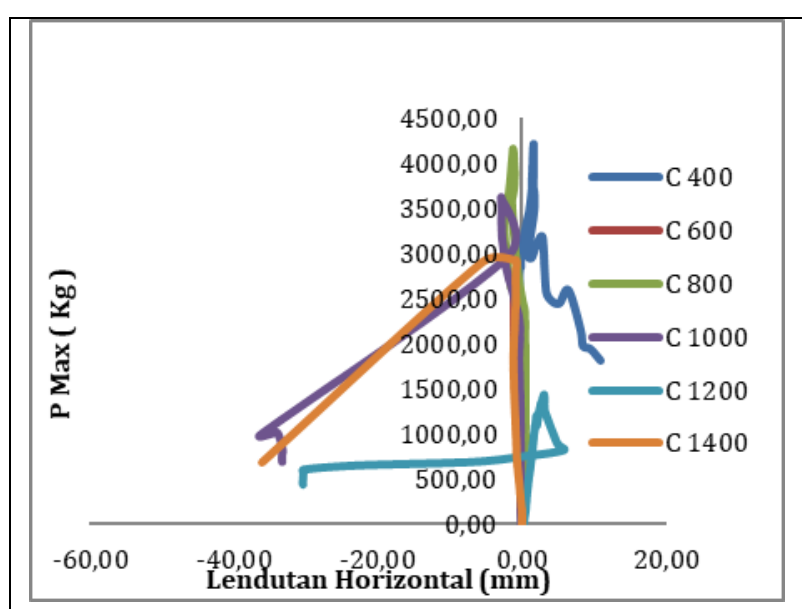

Gambar 8a. Grafik hubungan P mak dan lendutan horizontal batang komposit (C1-TR6)

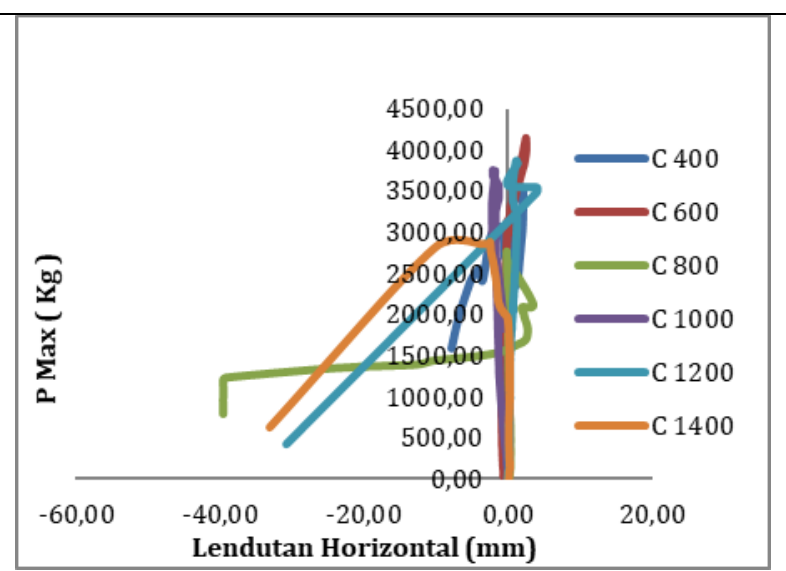

Gambar 8c. Grafik hubungan P mak dan lendutan horizontal batang komposit (C3-TR6)

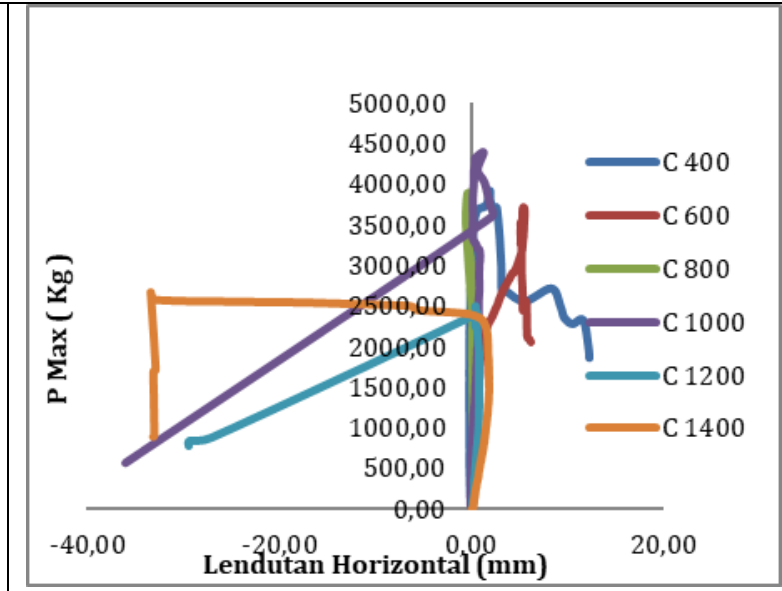

Gambar 8b. Grafik hubungan P mak dan lendutan horizontal batang komposit (C2-TR6)

Penjelasan :

Lendutan Horizontal batang komposit pada Tranduser $(\mathrm{Tr}-$ 6) bervariasi dan mendekati nol , kecuali untuk batang dengan panjang 1400 menunjukan bahwa lendutan yang terjadi mendekati benda uji, lendutan negatif (-) terjadi pada C2-1400 dengan lendutan $-33.32 \mathrm{~mm}$, hal ini menunjukan bahwa flens batang 1400 mengalami kerusakan dengan menekuk ke bagian dalam atau mendekati garis netral. Dari gambaran tersebut pada batang komposit terjadi kerusakan pada bagian atas atau bawah batang yang menunjukkan rata rata terjadi tekuk local, sementara untuk panjang batang 1400 mengalami tekuk lentur

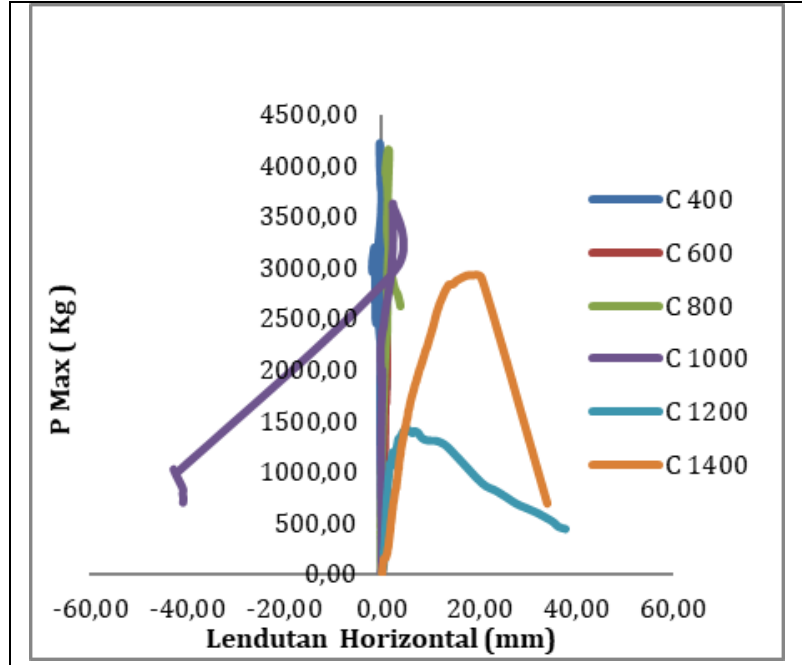

Gambar 9a. Grafik hubungan P mak dan lendutan horizontal batang komposit (C1-TR7)

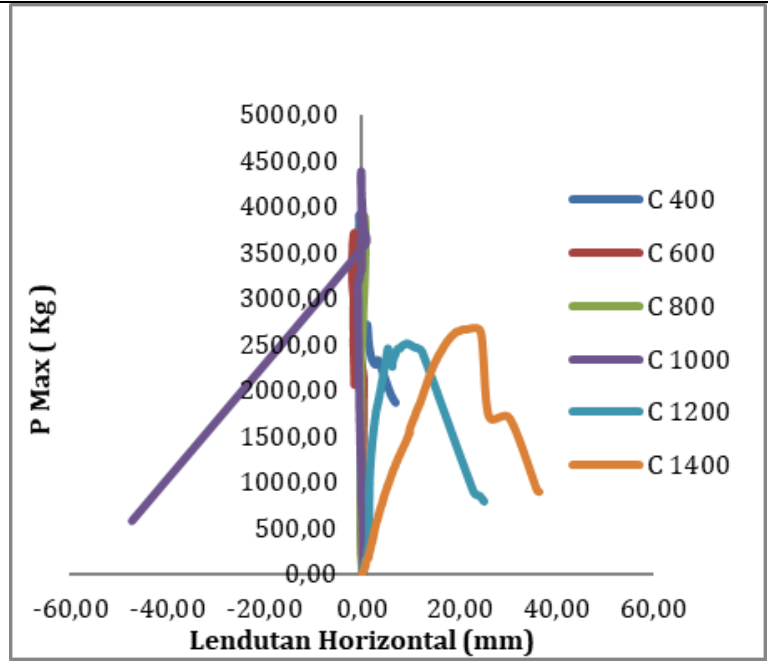

Gambar 9b. Grafik hubungan P mak dan lendutan horizontal batang komposit (C2-TR7) 


\section{Cahyadi dan Resmi Bestari Muin}

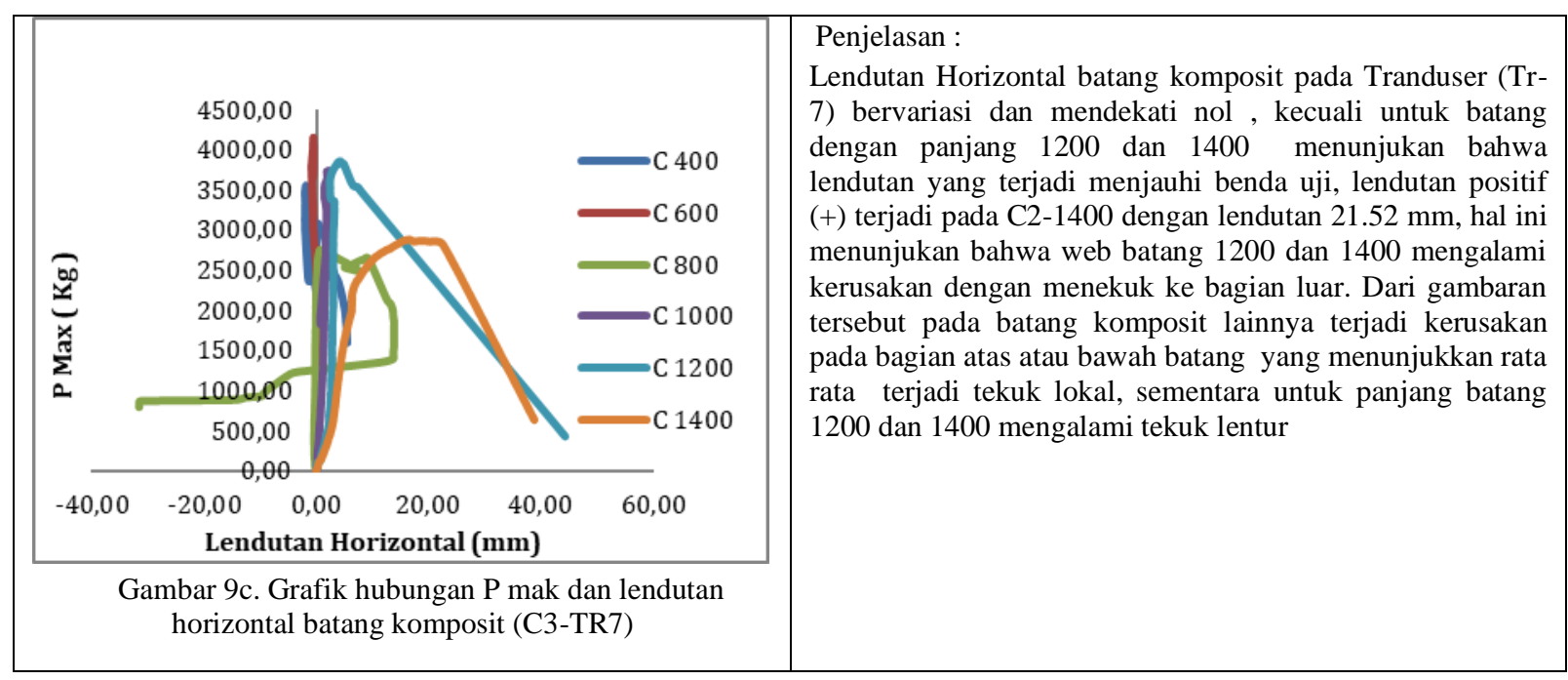

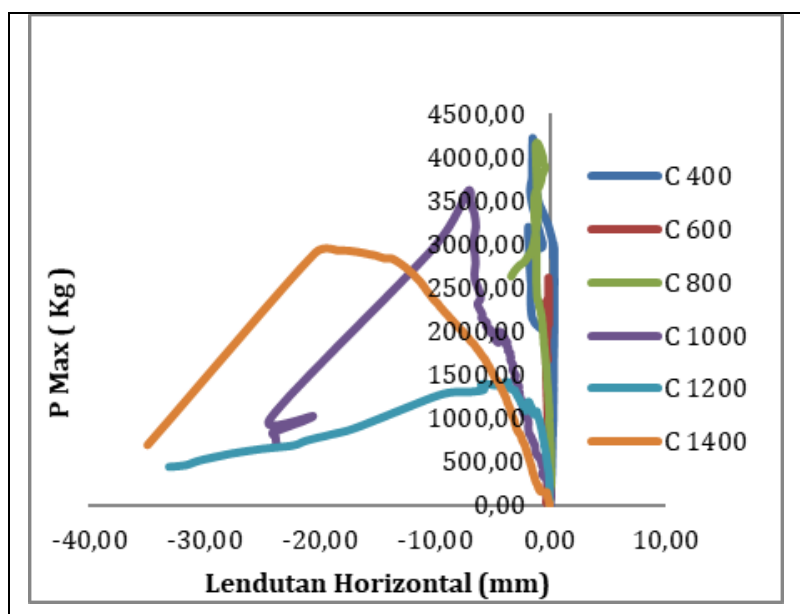

Gambar 10a. Grafik hubungan P mak dan lendutan horizontal batang komposit (C1-TR8)

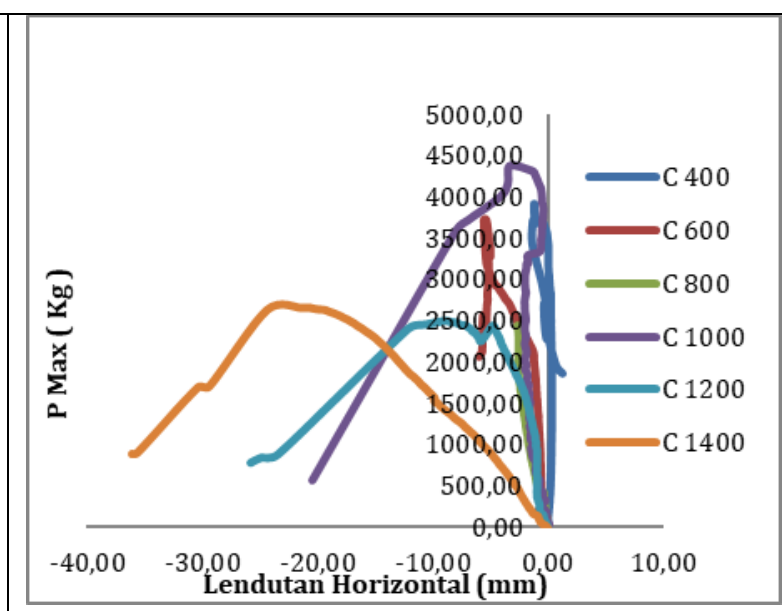

Gambar 10b. Grafik hubungan P mak dan lendutan horizontal batang komposit (C2-TR8)

Penjelasan :

Lendutan Horizontal batang komposit pada Tranduser ( $\mathrm{Tr}$ 8) bervariasi dan mendekati nol, kecuali untuk batang dengan panjang 1200 dan 1400 menunjukan bahwa lendutan yang terjadi mendekati benda uji, lendutan negatif maksimum (-) terjadi pada C2-1400 dengan lendutan -21.44 $\mathrm{mm}$, hal ini menunjukan bahwa web batang 1200 dan 1400 mengalami kerusakan dengan menekuk ke bagian dalam. Dari gambaran tersebut pada batang komposit lainnya terjadi kerusakan pada bagian atas atau bawah batang yang menunjukkan rata rata terjadi tekuk lokal, sementara untuk panjang batang 1200 dan 1400 mengalami tekuk lentur 


\section{Kesimpulan}

Berdasarkan eksperimen beban maksimum $\left(P_{\text {mak }}\right)$ batang komposit antara 48.35 $\%$ sd $86.32 \%$ lebih besar dari batang non komposit. Komposit baja ringan casting plaster mempunyai pengaruh besar dalam meningkatkan kekuatan batang dalam menerima beban tekuk. Pola keruntuhan yang terjadi pada batang non komposit rata rata terjadi tekuk lentur, dimana batang mengalami kerusakan pada bagian tengah batang dengan rusaknya flens, lips dan web, yang selanjutnya batang terjadi tekuk sebelum batang leleh. Sementara pada batang komposit rata rata terjadi tekuk lokal, tekuk yang diawali dengan rusaknya batang pada bagian flens dan lips di bagian ujung yang lebih dahulu meleleh sebelum terjadi tekuk, kecuali pada $\left(L_{k}\right) 1200 \mathrm{~mm}$ dan $1400 \mathrm{~mm}$ terjadi tekuk lentur. Kedepan akan dilakukan penelitian dengan analisa dan model lain yang lebih kritis dalam menghadapi perkembangan di dunia konstruksi. 


\section{BIBLIOGRAFI}

Aidil Fitrah, Ridho dan Herman, Hazmal. (2019). Studi Eksperimental Perilaku Tekan Baja Ringan Dengan Variasi Profil Penampang. Rang Teknik Journal Vol.2 No.1 Januari 2019.

Andreas, Azaria, \& Abduh, Muhamad. (2013). Identifikasi Rantai Pasok Baja Ringan Untuk Mendukung Pembangunan Rumah Tahan Gempa Di Indonesia (271K).

Apriani, Widya. (2019). Evaluasi Instabilitas Rangka Atap Baja Ringan Sesuai Sni 7971-2013. Jurnal Sains Dan Teknologi, 17(1), 16.

Awaludin, Ali, Rachmawati, Kundari, Aryati, Made, \& Danastri, Anindha Dyah. (2015). Development of cold formed steel-timber composite for roof structures: compression members. Procedia Engineering, 125, 850-856.

Deskarta, Putu. (2018). Perilaku Elemen Batang Baja Ringan Type C Dalam Menerima Beban Tekan.

Hayu,Gati A., Ahmad M.A., Syamsul A. (2019). Analisa Kapasitas Balok Komposit dengan Penghubung Gesr Kanal Baja Menggunakan Program Bantu Elemen Hingga. Konverensi Nasional Teknik Sipil (KoNTeks)-13 Inovasi Sains Dan Teknologi Dalam Penerapan Infrastruktur Berbasis Mitigasi Bencana Dan Berwawasan Lingkungan, 808, 25.

Irawati, Inggar Septhia, Awaludin, Ali, \& Sebastian, Nicholas Padua. (2017). The Performance of Cold-formed Steel Long-span Roof Structure Combined with Laminated Timber: Cold-formed Steel - Laminated Timber Composite. Procedia Engineering, 171, 1242-1249.

Rahmawati, Kundari, \& Isnantyo, Fajar Danur. (2019). Analisis Tekan Komposit Laminasi Kayu - Baja Ringan Berdasarkan Sni 7973-2013. Indonesian Journal of Civil Engineering Education, 4(2), 103-109.

Sandjaya, Arif, \& Suryoatmono, Bambang. (2018). Studi Eksperimental Batang Tekan Baja Canai Dingin Diperkaku Sebagian. Jurnal Teknik Sipil, 25(1), 19-24.

Stevens, Denny dan Tedianto, Leo S. (2018). Analisa Pengaruh Panjang Elemen Terhadap Kuat Tekan Dari baja Ringan Profil Kanal Dengan Metode Elemen Hingga. Jurnal Mitra Teknik Sipil Vol.1, No.1, Agustus 2018: Hlm 159-167.

Sucipta, Andry, Saggaff, Anis, \& Muliawan, Sutanto. (2013). Analisa Pola Keruntuhan Konstruksi Rangka Atap dengan Menggunakan Profil Baja Ringan. Sriwijaya University.

Sumirin, Sumirin. (2014). Perilaku Beban-Perpindahan Aksial Pre-Buckling dan PostBuckling pada Struktur Kolom Elastis. Media Komunikasi Teknik SipiL, 20(1), 5361. 
Studi Eksperimental dan Analisis Elemen Rangka Atap Baja Ringan Komposit Aplus Casting Plaster

Syamsudin, Septian Fajar, Susanti, Eka, \& Istiono, Heri. (2018). Analisis Komparasi Perencanaan Struktur Rangka Atap Baja Ringan Untuk Rumah Tipe 180 Dengan Tipe Kuda-Kuda Yang Berbeda. Prosiding Seminar Nasional Sains Dan Teknologi Terapan, 383-388.

Yusuf, M., \& Elvira, Elvira. (2014). Studi Eksperimental terhadap Unjuk Kerja Kudakuda Baja Ringan Profil C dengan Ketebalan 0, $60 \mathrm{Mm}$. Tanjungpura University. 